\title{
Effect of Sugarcane Bagasse Ash as Partial Cement Replacement on the Compressive Strength of Concrete
}

\author{
Sabir Ali ${ }^{*}$, Aneel Kumar, Samar Hussain Rizvi, Mohsin Ali, Israr Ahmed \\ Department of Civil Engineering, MUET, Jamshoro. \\ ${ }^{*}$ Corresponding author: sabirbaloch938@gmail.com
}

Abstract

The disposal of solid waste in open environment is a serious alarming concern that needs immediate attention from the researchers. The hazardous solid agro-industrial wastes which include: wheat straw ash, rice husk ash, corn cob ash and sugarcane bagasse ash (SCBA), having pozzolanic properties, have a versatile use in concrete. The solid pozzolana enhances the various concrete properties by the reaction of silicates with calcium hydroxide in the presence of water, which in result generate a saturated zone of calcium silicate hydrate (CSH) gel. This C-S-H gel reduces the amount of calcium hydroxide $\mathrm{C}(\mathrm{OH}) 2$ during the hydration process of cement. Very limited research works have been done on concrete by partially replacing cement with SCBA. This research work was focused on evaluating the properties of concrete by partially replacing cement with SCBA at $0,5,10$, and 15 percentages. Compressive strength, Strength activity index, and water absorption of all mixes were examined. And it was observed that all SCBA mixes showed an increase in compressive strength and at 10\% replacement the strength activity index was at a peak of $115.67 \%$, but all the SCBA mixes showed a strength activity index greater than $75 \%$ which satisfied the standard specification. The water absorption test for all SCBA mixes showed a slight increase in water absorption.

Keywords-Pozzolanic material, Sugarcane bagasse ash, compressive strength, cement replacement, Strength activity index

\section{Introduction}

$\mathrm{I}$ $\mathrm{N}$ the production of concrete, various materials and re-sources are utilized. The process in cement production, pyro-processing (heating raw materials above $1000^{\circ} \mathrm{C}$ to bring physical and chemical changes to the parent material), emits various amounts of gases and utilizes a huge quantity of resources as fuel [1]. In the contemporary world, there are two requirements of an engineer during any construction project: protecting the environment, and fulfilling the infrastructural requirements of the occupants. To fulfil the occupant's requirements, many resources are being utilized by the construction industry, which result in creating environmental dangers and hazards [2]. Researchers of many developing countries have worked on these wastes including fly ash [3], sugarcane bagasse ash [4] [5], rice husk ash [6][7], bamboo leave ash [8], wheat straw ash, groundnut shells [9], corn cob [10], and

ISSN: 2523-0379 (Online), ISSN: 1605-8607 (Print)

DOI: 10.52584/QRJ.1802.07

This is an open access article published by Quaid-e-Awam University of Engineering Science $\&$ Technology, Nawabshah, Pakistan under CC BY 4.0 International License. produced metakaolin [11][12]. These materials enhance the behaviour of concrete and contribute to an ecofriendly environment [13][14].

With the addition of pozzolanic materials, different properties of concrete like flow-ability, strength, quality, durability and crack resistance can be improved [15]. Several advanced cement blends are produced by adding admixtures, which by pozzolanic reactions, ameliorate the micro-structure by minimising the concentration of calcium hydroxide [16]. The changes in the micro-structure of concrete composites improve mechanical behaviour and extend the service life. At the point when fine pozzolanic particles are scattered in the cement paste, they create an enormous number of nucleation places for the precipitation of hydration items and make the cement paste further homogeneous [17]. This is because of the reaction between silica $\left(\mathrm{SiO}_{2}\right)$ of pozzolana and calcium hydroxide (which is not favourable for cement hydration), delivered during the cement hydration reaction and produce additional calcium silicate hydrate CSH gel. In addition to the dense packing, this will reduce the wall effect between 
the paste and aggregate [18]. Janjaturaphan et. al. [4] studied the pozzolanic activity of SCBA and concluded that the improvement in the properties of concrete is due to filling ability and pozzolanic reactions of $\mathrm{SiO}_{2}$ present in SCBA and $\mathrm{C}(\mathrm{OH})_{2}$ in cement hydration. The filling ability is governed by the shape, size, and texture of SCBA particles and the pozzolanic reactions depend upon the percentage of $\mathrm{SiO}_{2}$ in the parent SCBA particles. Cordiero et. al. [19] observed that the pozzolanic reactivity of SCBA depends on the burning temperature; the suitable temperature being up to $500^{\circ} \mathrm{C}$ producing amorphous $\mathrm{SiO}_{2}$ which is highly reactive.

López et. al. [20] studied the effect of natural pozzolana on porosity and pore connectivity of concrete and found that the pozzolanic activity in the produced concrete had a great impact on durability of concrete. With a replacement of $33 \%$ of cement with natural pozzolana, the permeability of concrete reduced up to $200 \%$ and greatly reduced the water absorption and as well as chloride ion penetration at 84 days curing. Lathamaheswari et. al. [14] deduced that by replacing cement with SCBA, workability of the concrete mix is reduced due to the water absorption of SCBA particles, and the compressive and tensile strength increased due to extra C-S-H gel, which were maximum at $10 \%$ replacement with $35.23 \mathrm{~N} / \mathrm{mm} 2$ and $3.59 \mathrm{~N} / \mathrm{mm} 2$ respectively at 28 days curing and a $\mathrm{w} / \mathrm{b}$ ratio of 0.5. But modulus of rupture increased on all replacement levels up to $12.5 \%$. Mohd et. al. [21] utilized SCBA and sawdust ash in concrete and examined fresh and hard-ened properties. Cement was partially replaced with SCBA and SDA in varying percentages of 0,5 , and 10 . The proportion of SCBA and SDA were kept the same (1:1) in all percentages. Fresh properties of concrete were checked by performing slump cone and compaction factor tests, and it was noted that with the increase of SCBA and SDA amount in the mix, there was a great decrease in workability due to the water absorption by SCMs. Compressive strength of SCBA and SDA made concrete at 7 days of curing indicated a reduction in strength. At 28 days of curing compressive strength of blended concrete enhanced by $5.79 \%$ at a replacement level of $5 \%$. Furthermore, Minnu et. al. [22] reviewed the effectiveness of SCBA as a pozzolanic material in comparison with fly ash and ground granulated blast furnace slag in terms of various properties of concrete. SCBA being lighter in weight reduced the density of concrete as compared to FA and GGBFS. The fineness of all SCMs had a great impact on the rate of reaction with $\mathrm{C}(\mathrm{OH})_{2}$. The incorporation of SCBA retarded the setting of concrete mixes by more than $40 \%$ as compared to FA and
GGBFS. The optimum percentages of SCBA, FA, and GGBFS in terms of strength were reported as 20, 30, and 40. In addition to strength, all the SCMs increased durability due to the reduction of permeability and alkali-silica reaction.

In tropical countries, sugarcane is the main source used for the production of sugar in sugar mills. Bagasse is left behind as trash after the extraction of juices in the sug-arcane, which is used for fuel purposes in the containers to generate energy by the co-generation process, and sugarcane bagasse ash is produced which is a solid waste and nuisance to the environment [15]. Sugar industries play a major role in the economy of Pakistan. According to a report published by the Pakistan sugar mills association in 2015-2016, countrywide sugarcane production was 65.4 million tonnes and was continuously growing on yearly bases [23]. Very limited research work has been done on the sugarcane bagasse ash (SCBA) of matiari region as pozzolana in cement.

The study presented in this paper aims to check the effectiveness of SCBA as sup-plementary cementitious material on conventional concrete with $0 \%, 5 \%, 10 \%$, and $15 \%$ replacement of cement.

\section{Materials \& Methodology}

To check the influence of sugarcane bagasse ash on the compressive strength and water absorption in conventional concrete, sugarcane bagasse ash (SCBA) was collected from matiari sugar mill in Sindh Pakistan, and the chemical composition of SCBA was checked according to the ASTM standard [24]. The collected SCBA, shown in Figure 2, is sieved from a 45t $\mu$ m (325 No.) sieve. OPC of DG cement factory conforming to ASTM Standard C150 [25] is used. Locally available Bholari sand was used which has a specific gravity of 2.69. Coarse aggregates were collected from Nooriabad crush factory having a specific gravity of 2.605. The aggregates were made to pass from a $20 \mathrm{~mm}$ sieve and retained on $4.75 \mathrm{~mm}$. The passed aggregates were then washed properly to remove the dusty particles. Physical and chemical properties of the materials used are shown in Table 1-2. Four cement blends were prepared by partially replacing OPC at $0,5,10$, and 15 percentages with SCBA. Total 24 cylinders of standard size of $100 \mathrm{~mm} \times 200 \mathrm{~mm}$ for compressive strength and 12 cubes of standard size $100 \mathrm{~mm} \times 100 \mathrm{~mm}$ for water absorption were casted. For each mix, 6 cylinders and 3 cubes were casted with 3 cylinders for 7 days strength and 3 cylinders for 28 days strength. Water absorption tests were performed on the cubes after 28 days of curing. All the mix proportions were mixed by using a mechanical mixer machine, (Figure 1) and the mix 


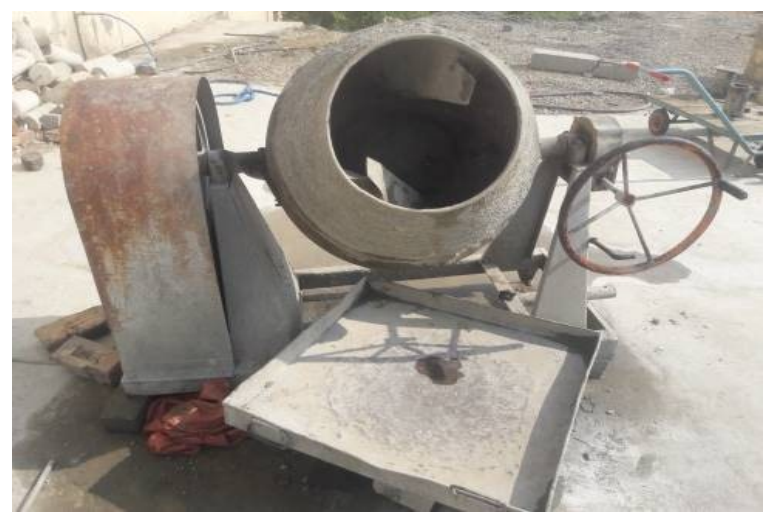

Fig. 1: Mixer machine

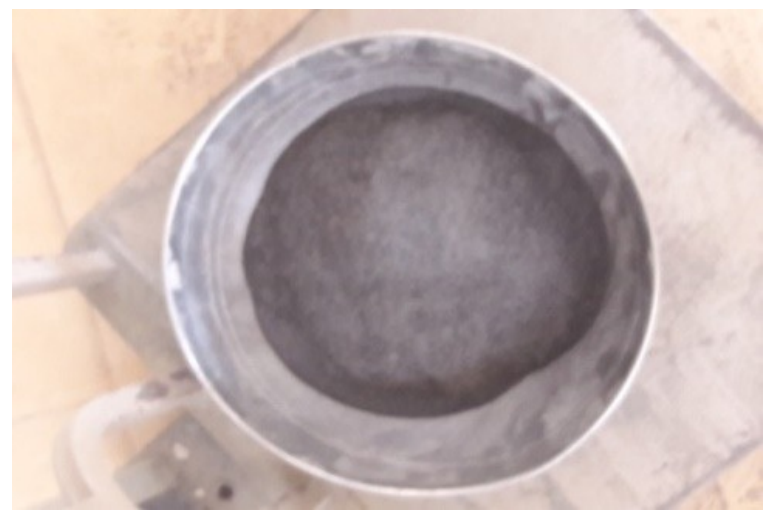

Fig. 2: Sugarcane bagasse ash after sieving from No. 325

ratio was kept at 1:1.5:3 at a water/binder ratio of 0.52 . The specific mix proportion is selected from the nominal mix of M20. Different mix proportions obtained by partially replacing cement with different percentages of SCBA are shown in Table 3.

\section{Results \& Discussion}

The following sections describe the results of this study.

\subsection{Compressive Strength}

The compressive strengths of all mixes were determined by cylindrical specimens of $100 \mathrm{~mm} \times 200 \mathrm{~mm}$ according to ASTM C39 [32]. The average compressive strength was determined by testing three samples of each concrete mix using the Universal Testing Machine (UTM) shown in photograph 3. Values of average compressive strengths of each mix are given in Table 4 and Fig. 3, 4, and 5.

Compressive strengths of all concrete mixes are shown in the above figures. The results in Figure 3-4 show that there is no such development in the early age

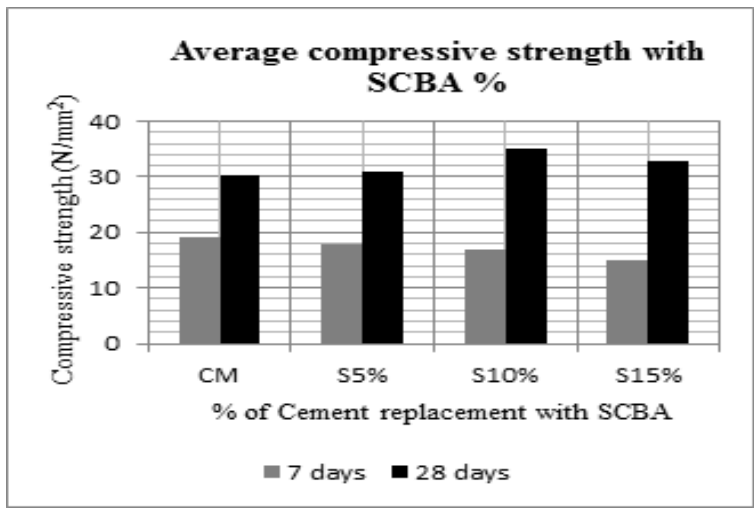

Fig. 3: Compressive strength of CM and SCBA concrete

strength of blended cement concrete, and the strength of the concrete mix without SCBA $\left(19.05 \mathrm{~N} / \mathrm{mm}^{2}\right)$ was greater than the strengths SCBA made concrete at 7 days curing period. The strengths of SCBA made concrete were $17.93 \mathrm{~N} / \mathrm{mm}^{2}, 16.98 \mathrm{~N} / \mathrm{mm}^{2}$, and 14.92 $\mathrm{N} / \mathrm{mm}^{2}$ at $5 \%, 10 \%$ and $15 \%$ replacement of cement with SCBA, respectively. But after 28 days of curing, the compressive strength of blended concrete showed much greater strength than the control mix. Compressive strength of all the mixes after 28 days were $30.17 \mathrm{~N} / \mathrm{mm}^{2}, 30.8 \mathrm{~N} / \mathrm{mm}^{2}, 34.9 \mathrm{~N} / \mathrm{mm}^{2}$ and 32.72 $\mathrm{N} / \mathrm{mm}^{2}$ at $0,5,10$ and 15 percent replacement of cement with SCBA, respectively. Strength enhancement started at a replacement level of $5 \%$ and was optimum at $10 \%$ replacement of cement with SCBA, and showed a reduced value at $15 \%$.

In the chart of strength activity index shown in Figure 5, it can be seen that all SCBA blended mixes showed greater values than $75 \%$ which satisfies ASTM C618 [24]. The peak value of SAI was $115.67 \%$ and reported at a $10 \%$ replacement level. The SAI of all mixes were $100 \%, 102.08 \%, 115.67 \%$ and $108.45 \%$ at $0 \%, 5 \%, 10 \%$ and $15 \%$ replacement of cement with SCBA, respectively.

$$
\text { Strength activity index }=\frac{A}{B} \times 100
$$

Where $A$ is the strength of concrete with blended cement, and $B$ is the strength of concrete with OPC The failure patterns were same for all the replacement levels, as shown in Figure 7-8. The patterns for 0, 5, 10 and $15 \%$ were same as type 2 in ASTM C39 [32]. Cracks started to generate from the top on the cylinders and travelled down forming a well-formed cone at the bottom side. 


\begin{tabular}{|l|l|l|l|l|l|l|l|l|l|l|}
\hline $\begin{array}{l}\text { Chemical } \\
\text { Constituents \% }\end{array}$ & $\mathrm{SiO}_{2}$ & $\mathrm{Al}_{2} \mathrm{O}_{3}$ & $\mathrm{Fe}_{2} \mathrm{O}_{3}$ & $\mathrm{CaO}$ & $\mathrm{MgO}$ & $\mathrm{SO}_{3}$ & $\mathrm{~K}_{2} \mathrm{O}$ & $\mathrm{Na}_{2} \mathrm{O}$ & $\mathrm{LoI}$ & $\mathrm{SiO}_{2}+\mathrm{Al}_{2} \mathrm{O}_{3}+\mathrm{Fe}_{2} \mathrm{O}_{3}$ \\
\hline $\mathrm{SCBA}$ (class N) & 67.3 & 5.34 & 4.27 & 1.9 & 1.23 & 0.29 & 4.26 & 0.95 & 10.48 & 76.91 \\
\hline $\mathrm{OPC}$ & 23.6 & 4.71 & 2.32 & 62.7 & 2.05 & 2.15 & 0.46 & 0.49 & 1.5 & - \\
\hline
\end{tabular}

TABLE 1: Chemical constituents of SCBA and OPC

\begin{tabular}{|l|l|l|l|}
\hline Material & \multicolumn{2}{|l|}{ Property } & Relevant Standard \\
\hline \multirow{4}{*}{ OPC } & Specific Gravity & 3.15 & ASTM C188 $[26]$ \\
\cline { 2 - 4 } & Fineness & 4 & ASTM C786 $[27]$ \\
\cline { 2 - 4 } & Consistency & 32 & ASTM C187 [28] \\
\cline { 2 - 4 } & In. Setting time & 45 & ASTM C191 $[29]$ \\
\cline { 2 - 4 } & Fi. Setting time & 250 & ASTM C191 \\
\hline \multirow{2}{*}{ Fine aggregate } & Specific gravity & 2.69 & ASTM C128 [30] \\
\cline { 2 - 4 } & Water absorption & 1.3 & ASTM C128 \\
\hline \multirow{2}{*}{ Coase Aggregate } & Specific gravity & 2.605 & ASTM C127 [31] \\
\cline { 2 - 4 } & Water absorption & 0.7 & ASTM C127 \\
\hline
\end{tabular}

TABLE 2: Properties of materials

\begin{tabular}{|c|c|c|c|c|c|c|c|c|c|}
\hline \multirow{2}{*}{$\begin{array}{l}\text { Mix } \\
\text { Proportion }\end{array}$} & \multirow{2}{*}{\multicolumn{2}{|c|}{$\begin{array}{l}\text { Binder content } \\
\text { in } \%\end{array}$}} & \multirow{2}{*}{$\begin{array}{l}\text { F. \& } \\
\text { C.Aggregate } \\
\%\end{array}$} & \multirow{2}{*}{$\begin{array}{l}\text { W/B } \\
\text { Ratio }\end{array}$} & \multicolumn{5}{|c|}{ Amount of quantities in $\mathrm{Kg}$} \\
\hline & & OPC & & & SCBA & OPC & F.Aggregate & C.Aggregate & Water \\
\hline $\mathrm{CM}$ & 0 & 100 & 100 & 0.52 & 0 & 340 & 510 & 1020 & 176.8 \\
\hline S5\% & 5 & 95 & 100 & 0.52 & 17 & 323 & 510 & 1020 & 176.8 \\
\hline S10\% & 10 & 90 & 100 & 0.52 & 34 & 306 & 510 & 1020 & 176.8 \\
\hline S15\% & 15 & 85 & 100 & 0.52 & 51 & 289 & 510 & 1020 & 176.8 \\
\hline
\end{tabular}

TABLE 3: Mix proportion required for $1 \mathrm{~m}^{3}$ of concrete

\begin{tabular}{|l|l|l|l|}
\hline \multirow{2}{*}{ No. } & \multirow{2}{*}{ Mix } & \multicolumn{2}{|l|}{$\begin{array}{l}\text { Average Compressive } \\
\text { Strength (N/mm2) }\end{array}$} \\
\cline { 3 - 4 } & & $\mathbf{7}$ days & $\mathbf{2 8}$ days \\
\hline 1 & $\mathrm{CM}$ & 19.05 & 30.17 \\
\hline 2 & $\mathrm{~S} 5 \%$ & 17.93 & 30.8 \\
\hline 3 & $\mathrm{~S} 10 \%$ & 16.98 & 34.9 \\
\hline 4 & $\mathrm{~S} 15 \%$ & 14.92 & 32.72 \\
\hline
\end{tabular}

TABLE 4: Compressive strengths of all cylindrical concrete mixes

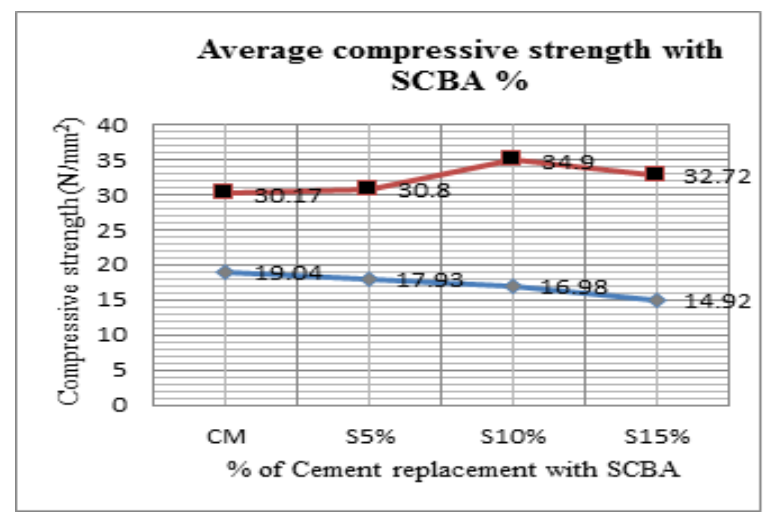

Fig. 4: 7 and 28 days compressive strength

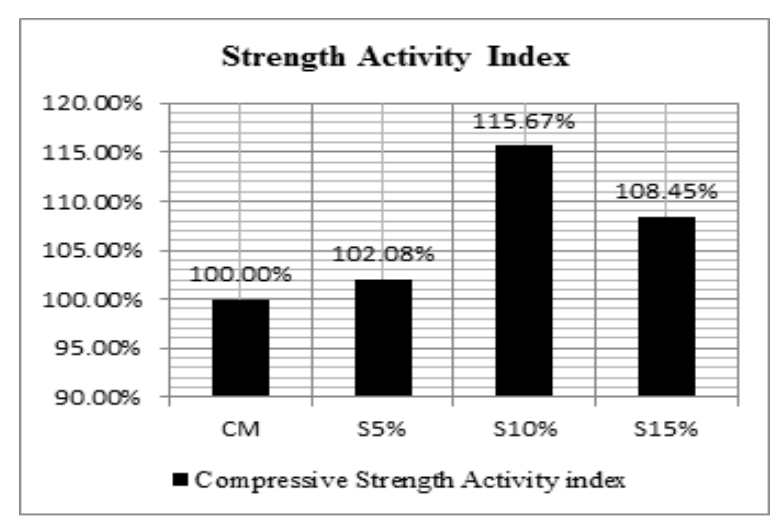

Fig. 5: Strength activity strength of SCBA with CM

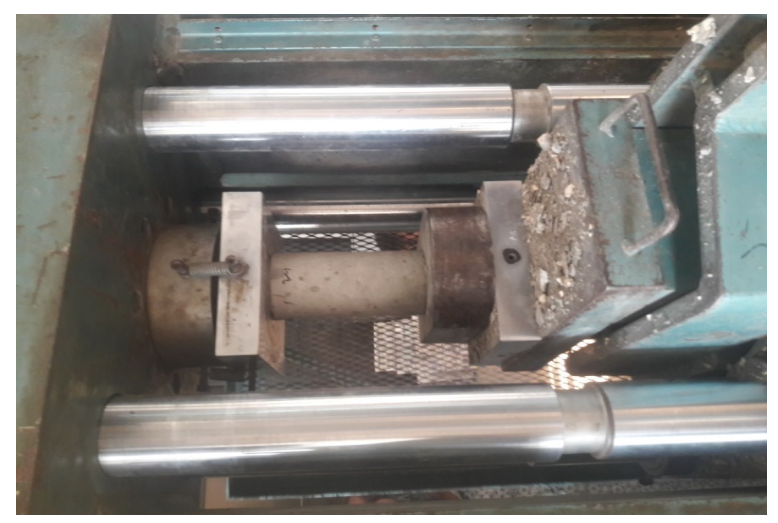

Fig. 6: Compression test of Cylinders 

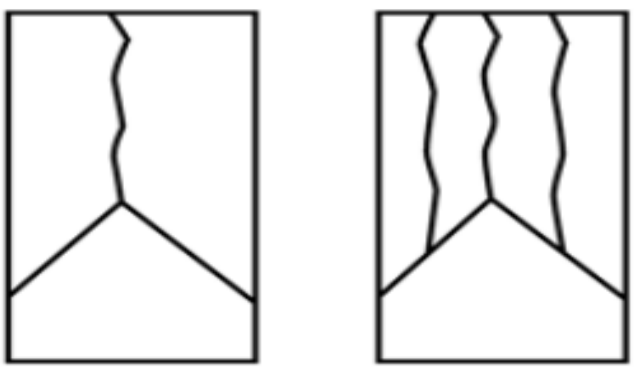

Fig. 7: Type 2 well-formed cone on one end, vertical cracks running through caps, no well-defined cone on other end (Failure pattern in ASTM C39 [32])

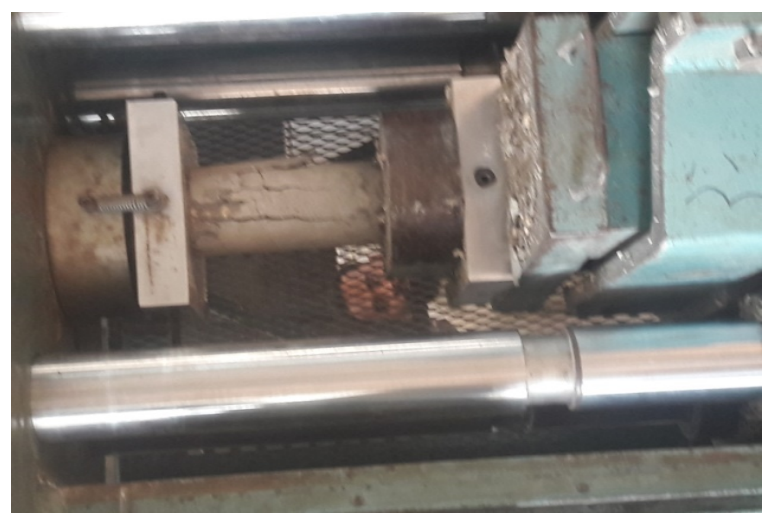

Fig. 8: Failure patterns of cylinders

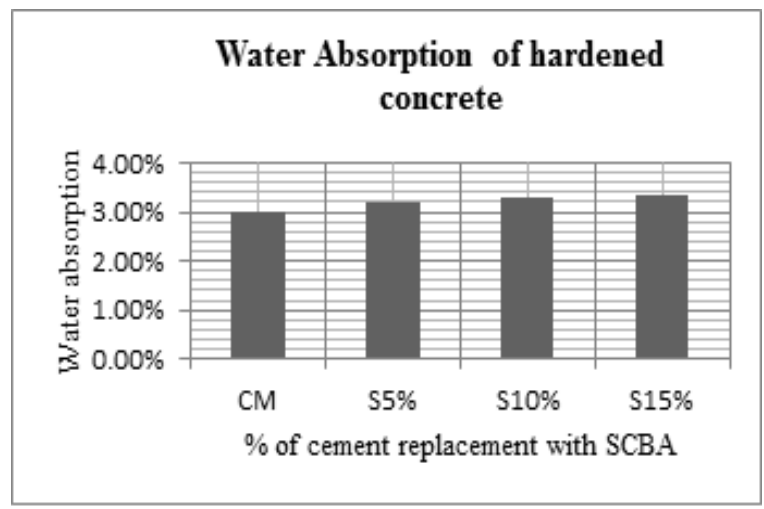

Fig. 9: Water absorption of concrete mixes after 28 days curing

\begin{tabular}{|l|l|l|}
\hline Sr. No & Mix & Water absorption (\%) \\
\hline 1 & CM & 3.01 \\
\hline 2 & S5\% & 3.20 \\
\hline 3 & S10\% & 3.31 \\
\hline 4 & S15\% & 3.35 \\
\hline
\end{tabular}

TABLE 5: Water absorption of hardened concrete

\subsection{Water Absorption}

Water absorption tests were carried out according to BS 1881-122:1983 [33]. After 28 days of curing, weights of three cubical specimens for each mix were noted and placed in oven for 24 hours at a temperature of $105^{\circ} \mathrm{C}$. After 24 hours, weights of specimens were again noted and the values of water absorption for different mixes were determined. The calculated water absorption was $3.01 \%, 3.2 \%, 3.31 \%$ and $3.35 \%$ at $0 \%, 5 \%, 10 \%$ and $15 \%$ replacement of cement with SCBA, respectively. Different values of water absorption in percentages are shown in Table 5. With increase in the amount of SCBA, water absorption of the concrete specimen also increased. Maximum value of water absorption was at 15\% SCBA mix. As shown in Table 5 and Figure 9, water absorption of SCBA blended concrete gradually varied in increasing order at all replacement percentages of cement with SCBA. In comparison with the control mix, $5 \%$ replacement showed $6.31 \%$ increase in water absorption, $10 \%$ replacement showed $9.9 \%$ increase in water absorption, and 15\% replacement showed $11.29 \%$ increase in water absorption respectively.

\section{Conclusion}

From the experimental results of cement partially relaced with SCBA in conventional concrete, the following points were concluded.

- SCBA blended concrete showed great improvement in compressive strength. Maximum compressive strength of $34.9 \mathrm{~N} / \mathrm{mm} 2$ was achieved at 10\% SCBA. All the SCBA made concrete mixes showed increase in compressive strength of concrete.

- However, all mix proportions showed a value ofSAI greater than $75 \%$. Maximum SAI value was calculated at $10 \%$ SCBA which is $115.67 \%$. The maximum SAI of $108.45 \%$ was achieved at $15 \%$ replacement of cement with SCBA.

- The optimum percentage of SCBA is concluded to be at $10 \%$ replacement of cement with SCBA.

- SCBA blended concrete at all replacement percentages gave more water absorption than the control mix. The increase in the water absorption is due to the high water demand of SBCA. 


\section{References}

[1] M. Stajanca and A. Estokova, "Environmental Impacts of Cement Production," Tech. Univ. Kosice, Civ. Eng. Fac. Inst. Archit. Eng., pp. 296-302, 2012, [Online]. Available: http://ena.lp.edu.ua:8080/bitstream/ntb/16692/1/55Stajanca-296-302.pdf.

[2] G. N. K. Reddy, G. H. Vardhan, and S. V. B. Reddy, "Partial Replacement of Cement in Concrete with Sugarcane Bagasse Ash and its Behaviour in Aggressive Environments," IOSR J. Mech. Civ. Eng., vol. 16, no. 053, pp. 29-35, 2016.

[3] V. Subbamma and K. Chandrasekhar Reddy, "Experimental study on compressive strength of plain cement concrete with partial replacement of cement by Flyash Metakaolin," Int. J. Civ. Eng. Technol., vol. 7, no. 6, pp. 82-89, 2016.

[4] S. Janjaturaphan and S. Wansom, "Pozzolanic activity of industrial sugar cane bagasse ash," Suranaree J. Sci. Technol., vol. 17, no. 4, pp. 349-357, 2010.

[5] K. Prajapati, "Experimental Investigation on Strength of Concrete by Partial Replacement of Cement by Dolomite Powder," Int. J. Res. Appl. Sci. Eng. Technol., vol. 7, no. 5, pp. 2611-2616, 2019.

[6] K. Madhu, "Study on Partial Replacement of Cement With Rha and Metakaolin.," Int. J. Adv. Res., vol. 4, no. 12, pp. 300-305, 2016.

[7] S. C. Paul et al., "Agricultural solid waste as source of supplementary cementitious materials in developing countries," Materials, vol. 12, no. 7. MDPI AG, p. 1112, 2019.

[8] C. Maraveas, "Production of sustainable construction materials using agro-wastes," Materials (Basel)., vol. 13, no. 2, 2020.

[9] V. Guna et al., "Groundnut shell / rice husk agro-waste reinforced polypropylene hybrid biocomposites," J. Build. Eng., vol. 27, p. 100991, Jan. 2020.

[10] M. Massoudinejad et al., "Use of municipal, agricultural, industrial, construction and demolition waste in thermal and sound building insulation materials: A review article 09 Engineering 0912 Materials Engineering," Journal of Environmental Health Science and Engineering, vol. 17, no. 2. Springer, pp. 1227-1242, Jul. 02, 2019.

[11] P. Dinakar, P. K. Sahoo, and G. Sriram, "Effect of Metakaolin Content on the Properties of High Strength Concrete," Int. J. Concr. Struct. Mater., vol. 7, no. 3, pp. 215-223, 2013.

[12] A. SAAND, M. A. KEERIO, and D. khan BANGWAR, "Effect of Metakaolin Developed From Local Natural Material Soorh on Workability, Compressive Strength, Ultrasonic Pulse Velocity and Drying Shrinkage of Concrete," Archit. Civ. Eng. Environ., vol. 10, no. 2, pp. 115-122, 2017.

[13] K. S. Kumar et al., "A comprehensive study on partial replacement of cement with sugarcane bagasse ash, rice husk ash stone dust," Int. J. Civ. Eng. Technol., vol. 7, no. 3, pp. 163-172, 2016.

[14] G. Lathamaheswari, R., Kalaiyarasan, V and Mohankumar, "Study on Bagasse Ash As Partial Replacement of Cement in Concrete," Int. J. Civ. Eng. Technol., vol. 13, no. 1, pp. 1-6, 2017.

[15] A. B. Aher and V. M. Natraj, "Effect of Sugarcane Bagasse Ash on Workability of Concrete and Validation of Compressive Strength By Using Ann," Int. J. Adv. Res. Sci. Technol., vol. 5, no. 9, pp. 428-439, 2016.

[16] I. I. Shah et al., "Incorporation of Rice Husk Ash and Metakaolin as Partial Replacement of Cement in M20 Concrete," Int. Res. J. Eng. Technol., vol. 6, no. 6, pp. 1801-1811, 2019.
[17] R. Siddique and J. Klaus, "Influence of metakaolin on the properties of mortar and concrete: A review," Appl. Clay Sci., vol. 43, no. 3-4, pp. 392-400, 2009.

[18] N. John, "Strength Properties of Metakaolin Admixed Concrete," Int. J. Sci. Res. Publ., vol. 3, no. 6, pp. 1-7, 2013, [Online]. Available: www.ijsrp.org.

[19] G. C. Cordeiro, R. D. Toledo Filho, and E. de Moraes Rego Fairbairn, "Use of ultrafine rice husk ash with high-carbon content as pozzolan in high performance concrete," Mater. Struct., vol. 42, no. 7, pp. 983-992, Aug. 2009.

[20] M. López and J. T. Castro, "Effect of natural pozzolans on porosity and pore connectivity of concrete with time," Rev. Ing. construcción, vol. 25, no. 3, pp. 419-431, 2010.

[21] M. A. Fauzi, S. R. Rosseli, and M. J. A. Seman, "Utilisation of Sugarcane Bagasse Ash and Sawdust Ash as Cement Replacement Material in the Production of Structural Concrete," in Regional Conference on Science, Technology and Social Sciences (RCSTSS 2016), Springer Singapore, 2018, pp. 455-463.

[22] S. N. Minnu, A. Bahurudeen, and G. Athira, "Comparison of sugarcane bagasse ash with fly ash and slag: An approach towards industrial acceptance of sugar industry waste in cleaner production of cement," J. Clean. Prod., no. xxxx, pp. 1-21, Oct. 2020 ..

[23] S. A. Mangi et al., "Utilization of sugarcane bagasse ash in concrete as partial replacement of cement," IOP Conf. Ser. Mater. Sci. Eng., vol. 271, no. 1, 2017.

[24] ASTM C618, "Standard Specification for Coal Fly Ash and Raw or Calcined Natural Pozzolan for Use in Concrete," ASTM Int., pp. 1-5, 2019.

[25] ASTM C150, "ASTM C150/C150M Standard Specification for Portland Cement," Annu. B. ASTM Stand., pp. 1-10, 2019.

[26] ASTM C188, "Standard Test Method for Density of Hydraulic Cement," ASTM Int., pp. 1-3, 2017.

[27] ASTM C786, "Standard Test Method for Fineness of Hy-

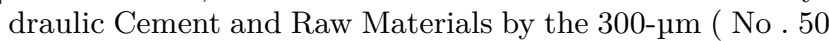

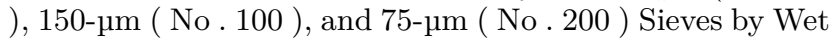
Methods," ASTM Int., pp. 1-4, 2017.

[28] ASTM C187, "Standard Test Method for Amount of Water Required for Normal Consistency of Hydraulic Cement Paste," ASTM Int., pp. 1-3, 2016.

[29] ASTM C191, "Standard Test Methods for Time of Setting of Hydraulic Cement by Vicat Needle," ASTM Int., pp. 1-8, 2019.

[30] ASTM C128, "Standard Test Method for Relative Density ( Specific Gravity ) and Absorption of Fine Aggregate," Annu. B. ASTM Stand., pp. 1-6, 2015.

[31] ASTM C127, "Standard Test Method for Relative Density (Specific Gravity) and Absorption of Coarse Aggregate," ASTM Int., pp. 1-5, 2015.

[32] ASTM C39, "Compressive Strength of Cylindrical Concrete Specimens," Annu. B. ASTM Stand., pp. 1-7, 2018.

[33] BS 1881-122:1983, "Method for determination of water absorption," Br. Stand. Inst., no. February, pp. 1-10, 2004. 